\title{
Effect of cold chain temperature abuses on the quality of frozen watercress (Nasturtium officinale R. Br.)
}

\author{
Rui M.S. Cruz ${ }^{\text {a }}$, Margarida C. Vieira ${ }^{\mathrm{b}}$, Cristina L.M. Silva ${ }^{\mathrm{a}, *}$

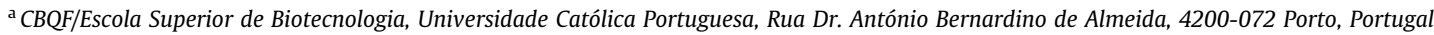 \\ ${ }^{\mathrm{b}}$ Escola Superior de Tecnologia, Universidade do Algarve, Campus da Penha, 8005-139 Faro, Portugal
}

\author{
Keywords: \\ Watercress \\ Frozen storage \\ Temperature abuses \\ Vitamin C \\ Colour \\ Microstructure \\ Modelling
}

\section{A B S T R A C T}

The objective of this work was to study the effect of temperature abuses on the colour and vitamin $\mathrm{C}$ content of a new frozen vegetable, watercress (Nasturtium officinale $\mathrm{R}$. Br.).

The vitamin C content, expressed as ascorbic (AA) and dehydroascorbic (DHAA) acids, and colour, expressed in the Hunter $L a b$ parameters, were evaluated along a plan of temperature abuses, based on a real situation for a four month frozen storage period. A comparison between the hue angle and AA experimental data and prediction models, using kinetic parameters determined under isothermal conditions, was also run.

The colour showed some variation, namely on the parameters $L, a$, TCD (Total Colour Difference) and hue angle. Although, during the temperature abuses, some fluctuation was observed, no vitamin $C$ degradation or major colour changes occurred. A zero-order and a first-order prediction models fitted well the experimental data for the hue angle and AA behaviour with temperature abuses, respectively. In general, the frozen watercress colour and vitamin $C$ content were not impaired by the imposed temperature abuses. This work will help to predict and understand the sensory and nutritional quality changes of frozen watercress that might occur during frozen storage and distribution in the cold chain under the used conditions.

\section{Introduction}

Watercress (Nasturtium officinale R. Br.) is a leafy vegetable of the family Cruciferae that grows in and around water. It is a good source of essential vitamins and minerals and beneficial phytochemicals, such as lutein and zeaxanthin (U.S. Department of Agriculture, 2003). Normally consumed fresh, it has a short shelf life (approximately seven days) that can be extended throughout freezing, allowing a longer period for distribution and storage.

Blanching is one of the pre-treatments used before freezing, to inactivate the enzymes and prevent biochemical reactions in the frozen product that might contribute for the development of offflavours and discoloration (Mountney and Gould, 1988). However, blanching causes undesirable changes in the food properties that may result in loss of colour, flavour, texture and nutrients (Pala, 1983; Pizzocaro et al., 1995).

The freezing process is an excellent method to preserve taste, texture and nutritional value of foods, and better than most other preservation methods. Nevertheless, such qualities depend upon the careful choice of food materials, suitable pre-treatments,

\footnotetext{
* Corresponding author. Tel.: +351 22 5580058; fax: +351 225090351.

E-mail addresses: rcruz@ualg.pt (R.M.S. Cruz), mvieira@ualg.pt (M.C. Vieira), clsilva@esb.ucp.pt (C.L.M. Silva).
}

choice of freezing process, and appropriate packaging and frozen storage options (Flair flow Europe, 2000; Blond and Le Meste, 2004).

Exposure to higher temperatures and/or fluctuations of storage temperature produces cumulative adverse effects on the quality of stored foods, which is the primary cause of damage to food marketed through retail channels (Blond and Le Meste, 2004).

The loss of quality is caused by physical and chemical changes taking place in the product. During the storage period, physical changes that affect frozen vegetables and fruits quality are a result of recrystallization and sublimation phenomena, related to the stability of the ice crystals inside and on the surface of the products. Recrystallization and surface drying are accelerated by temperature fluctuations during freezing, although the importance of these physical changes decreases at lower storage temperatures (Canet, 1989; Alvarez and Canet, 1998; Sousa et al., 2005).

New frozen product formulations and new freezing technologies benefits should be assessed taking into account the frequent temperature abuses occurring in commercial and domestic storage (Estrada-Flores, 2002).

In the distribution of frozen food, the cold chain starts at the raw material supplier and continues until the consumers' freezer, playing a very important role in the maintenance of food safety and quality. Therefore, in each major stage of the cold chain, 


\section{Nomenclature}

a colour co-ordinate, represents red to green

b colour co-ordinate, represents blue to yellow

C parameter concentration or value

$E_{\mathrm{a}} \quad$ activation energy $\left(\mathrm{kJ} \mathrm{mol}^{-1}\right)$

$k$ reaction rate $\left(\right.$ day $\left.^{-1}\right)$

L colour co-ordinate, represents black to white

$R \quad$ universal gas constant $\left(8.314 \mathrm{~J} \mathrm{~mol}^{-1} \mathrm{~K}^{-1}\right)$

$t$ time (days)
$T \quad$ absolute temperature (K)

TCD total colour difference parameter

Subscripts

$T \quad$ relative to a given temperature

$0 \quad$ initial value at time equal to zero

ref at the reference temperature temperature requirements must be taken into account. Usually, the suggested storage temperature is below $-18^{\circ} \mathrm{C}$, in which the microbial growth is completely stopped, and both enzymatic and non enzymatic changes continue but at much slower rates during frozen food shelf life, although temperature of $-15^{\circ} \mathrm{C}$ is permitted for short periods during transportation or local distribution. Moreover, food retail display cabinets should be at $-18{ }^{\circ} \mathrm{C}$ with good storage practice, but not warmer than $-12^{\circ} \mathrm{C}$. At the consumer's domestic freezers, storage temperature is also important, being the freezer 'star rating' related to its freezing capacity. A one-star freezer is capable of temperatures below $-6^{\circ} \mathrm{C}$, a two-star freezer of temperatures below $-12^{\circ} \mathrm{C}$, and a three-star freezer is capable of temperatures below $-18{ }^{\circ} \mathrm{C}$ (Flair flow Europe, 2000).

The objective of this work was to study the effect of temperature abuses on colour and vitamin $C$ content of frozen watercress and with the findings help to understand the sensory and nutritional quality changes that might occur during frozen storage and distribution in the food chain.

\section{Materials methods}

\section{Vegetable material}

Raw watercress (N. officinale R. Br.) was kindly supplied by Vitacress, a company that grows watercress in Almancil, Algarve-Portugal. The leaves were directly harvested from the producer and, on the same day, processed (selected, washed, blanched and frozen).

\section{Blanching and freezing processes}

The leaves of watercress were blanched in a boiling pan (Armfield $45 \mathrm{~L}$, Hampshire, England) in a proportion of $30 \mathrm{~g}$ per litre of water, set at $95{ }^{\circ} \mathrm{C}$ during $20 \mathrm{~s}$, and cooled in an iced water bath (Cruz et al., 2006). After the blanching process, the leaves ( $30 \mathrm{~g}$ ) were pressed in a mould into a slab shape $(4.6 \times 3.3 \times 1.8 \mathrm{~cm})$. The slabs were frozen in an air blast freezer (Armfield FT 36, Hampshire, England) at an average temperature of $-25^{\circ} \mathrm{C}$ and an air velocity of $8 \mathrm{~m} \mathrm{~s}^{-1}$, until the temperature of $-18^{\circ} \mathrm{C}$ was reached at the centre of the sample. Samples triplicates for each step of analysis were packed in low density polyethylene bags and stored at $-21^{\circ} \mathrm{C}$ (Haier HF-248, Germany). All temperatures were monitored with a digital thermometer (Ellab ctd 87, Roedovre, Denmark) and a thermocouple (1.2 mm needle dia; constantan-type T).

\section{Temperature abuses plan}

A plan of temperature abuses was established based on a real situation for a four month period (Oliveira et al., 2009) and applied to the frozen watercress packages (Fig. 1). The samples were stored in freezers (Haier HF-248, Germany) and analysed in each step of the plan (S1-S6 corresponds to production and distribution; S7S20 corresponds to consumer product purchase and storage). The watercress temperature was measured with a type $\mathrm{T}$ thermocouple placed in the slab thermal centre and recorded with a data acquisition system (Delta-T Devices DL2 e, Cambridge, England).

Factory

Load the Truck $\left(1 \mathrm{~h}\right.$ at $\left.25^{\circ} \mathrm{C}\right) \boldsymbol{S 2}$

Transportation

$\left(15 \mathrm{~min} / 4^{\circ} \mathrm{C} ; 45 \mathrm{~min} /-10^{\circ} \mathrm{C} ; 1 \mathrm{~h} /-18^{\circ} \mathrm{C}\right)$

$1^{\text {st }}$ distribution center

(unload the truck: $15 \mathrm{~min} / 4^{\circ} \mathrm{C}$ ) (transportation: $15 \mathrm{~min} /-10^{\circ} \mathrm{C} ; 1 \mathrm{~h} /-18{ }^{\circ} \mathrm{C}$ )

$2^{\text {nd }}$ distribution center (unload the truck: $15 \mathrm{~min} / 4^{\circ} \mathrm{C}$ ) (transportation: $15 \mathrm{~min} /-10^{\circ} \mathrm{C} ; 1 \mathrm{~h} /-18^{\circ} \mathrm{C}$ )

$3^{\text {rd }}$ distribution center

(unload the truck: $20 \mathrm{~min} /-10^{\circ} \mathrm{C}$ ) (distribution chamber: 3 days $/-21^{\circ} \mathrm{C}$ ) $\mathbf{S 3}$

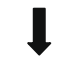

Load the retail car $\left(1 \mathrm{~h}\right.$ at $\left.25^{\circ} \mathrm{C}\right) \mathrm{S} 4$

Transportation $\left(15 \mathrm{~min} / 4{ }^{\circ} \mathrm{C} ; 15 \mathrm{~min} /-10{ }^{\circ} \mathrm{C}\right)$

$1^{\text {st }}$ to $8^{\text {th }}$ selling point* (unload the truck: $15 \mathrm{~min} / 4^{\circ} \mathrm{C}$ ) (transportation: $30 \mathrm{~min} /-15^{\circ} \mathrm{C}$ )

Last customer

(10 min at $\left.25^{\circ} \mathrm{C}\right) \mathrm{S5}$

(10 days $/-15^{\circ} \mathrm{C}$, night shutdown (12 h)) $\mathbf{S 6}$

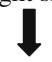

Consumer

(product purchase: $30 \mathrm{~min}$ at $25^{\circ} \mathrm{C}$ ) $\mathrm{S} 7$ (product storage: 3 months/at least $-18^{\circ} \mathrm{C}$; plus 5 door openings of $3 \mathrm{~min}$ and 1 door opening of $30 \mathrm{~min}$ per week (shopping simulation)) $\mathbf{S} \boldsymbol{8}-\boldsymbol{S} 20$

Fig. 1. Plan of temperature abuses. $S 1$ to $S 20$ - steps of analysis; ${ }^{*}$ These two steps were repeated eight $\times$. 
Colour was evaluated in terms of $L a b$ values, with a tristimulus colorimeter (Dr Lange Spectro-colour, Berlin, Germany) in the Hunter system (HunterLab, 2000). The colorimeter (d/8 ${ }^{\circ}$ geometry, illuminant D65, $10^{\circ}$ observer) was calibrated against a standard ceramic white tile $(X=84.60, Y=89.46$ and $Z=93.85)$ and a standard ceramic black tile $(X=4.12, Y=4.38$ and $Z=4.71)$. The colour changes were interpreted by calculating the TCD (Total Colour Differences) (Eq. (1)) where $\Delta L, \Delta a$ and $\Delta b$ are determined by Eq. (2). The hue angle (tone or tint) was determined by Eq. (3) and chroma (saturation) by Eq. (4). Measurements were taken in triplicates.

$$
\begin{aligned}
\mathrm{TCD} & =\sqrt{(\Delta L)^{2}+(\Delta a)^{2}+(\Delta b)^{2}} \\
\Delta L & =L-L_{0} \\
\Delta a & =a-a_{0} \\
\Delta b & =b-b_{0}
\end{aligned}
$$

where $L_{0}, a_{0}$ and $b_{0}$ are the readings of the frozen samples before temperature abuses, and $L, a$ and $b$ the individual readings at each step of the temperature abuses plan.

Hue angle $=\left(\tan ^{-1} b / a\right)$

Chroma $=\left(a^{2}+b^{2}\right)^{1 / 2}$

\section{Ascorbic acid and dehydroascorbic acid analysis}

Ascorbic acid (Riedel-de Haën) content was determined based on a method previously reported (Zapata and Dufour, 1992), by reverse phase ion interaction high performance liquid chromatography HPLC UV detection using isoascorbic acid (IAA) (Fluka) as internal standard. Dehydroascorbic acid (Sigma) was as well detected as fluorophore 3-(1,2-dihydroxyethyl)furo[3,4-b]quinoxaline-1-one (DFQ), after pre-column derivatization with 1,2-phenylenediamine dihydrochloride (OPDA) (Sigma).

For the mobile phase, $13.61 \mathrm{~g}$ of potassium dihydrogen phosphate (Merk) and $3.64 \mathrm{~g}$ of cetrimide (Fluka) were added to $2 \mathrm{l}$ of methanol-ultrapure water $(5: 95, v / v)$. The eluent was filtered in a $0.45 \mu \mathrm{m}$ membrane (Macherey-Nagel, Porafil) and degassed in an ultrasonic bath for 15 min. The HPLC system consisted of a controller (LKB-2152, Bromma, Sweden), a solvent pump (LKB-2150, Bromma, Sweden), an injection valve with a $20 \mu \mathrm{l}$ sample loop, a guard pre-column (Macherey-Nagel, Chromcart Nucleosil 100-10 C18) followed by a reversed phase column (Macherey-Nagel, Chromcart 100-10 Nucleosil, $250 \times 4.6 \mathrm{~mm}$ ) and a UV detector (LKB-2153, Bromma, Sweden).

Each sample was homogenized with an Ultra-turrax (IKA T25 Janke \& Kunkel, Staufen, Germany) in $20 \mathrm{ml}$ of methanol-ultrapure water $(5: 95, \mathrm{v} / \mathrm{v})$ for $5 \mathrm{~min}$ at $8000 \mathrm{rpm}$. Then, $5 \mathrm{ml}$ were transferred to a $20 \mathrm{ml}$ volumetric flask and $1 \mathrm{ml}$ of IA standard solution $(0.03 \mathrm{~g} / 50 \mathrm{ml})$ was added. The $\mathrm{pH}$ was adjusted with $\mathrm{HCl}$ (Merk) to obtain final values between 2.20 and 2.45 . The volume was completed to $20 \mathrm{ml}$ with methanol-ultrapure water $(5: 95, \mathrm{v} / \mathrm{v})$. The content was centrifuged (Sigma $3 \mathrm{~K} 20$, Osterode, Germany) for $5 \mathrm{~min}$ at $8.720 \times \mathrm{g}$ and $4^{\circ} \mathrm{C}$. Afterwards, $3 \mathrm{ml}$ were transferred to another tube with $1 \mathrm{ml}$ of OPDA (Sigma) $(0.03 \mathrm{~g} / 50 \mathrm{ml})$ daily prepared and maintained in dark. The mixture was then vortexed and placed in the dark at room temperature for $40 \mathrm{~min}$. Then the mixture was filtered in a $0.45 \mu \mathrm{m}$ membrane (Millipore), the first millilitre was discarded and $20 \mu$ l were injected in the HPLC. The wavelength detector was set to $348 \mathrm{~nm}$ and after elution of DHAA, the wavelength was shifted to $262 \mathrm{~nm}$ for AA and IA detection. The experiments were run in triplicate.
Tissue microstructure was only examined to evaluate the effect of the blanching process. Thus, after blanching, the leaves were stored in a vertical freezer at $-80{ }^{\circ} \mathrm{C}$ (Snijders Scientific, Tilburg, The Netherlands). Afterwards, based on the method reported by Fonseca et al. (2005), the samples were transversally cut with a surgery thin blade and observed in a scanning electron microscope (SEM) (JEOL JSM-5600 LV, Tokyo, Japan) at low vacuum with an acceleration voltage of $15 \mathrm{kV}$ and a cryo-chamber set at $-25^{\circ} \mathrm{C}$. The experiments were run with six replicates.

\section{Prediction of ascorbic acid and hue value}

The ascorbic acid and hue angle experimental data were compared with prediction models (using the kinetic parameters estimated under isothermal conditions (Table 2) (Gonçalves et al., 2009), in which the integration of the temperature variability with time was required.

The reaction rate $k_{\mathrm{T}}$, for which the temperature dependence followed the Arrhenius behaviour, was calculated using Eq. (5):

$k_{\mathrm{T}}=k_{\text {ref }} \exp \left[\left(-\frac{E_{a}}{R}\right)\left(\frac{1}{T}-\frac{1}{T_{\text {ref }}}\right)\right]$

Where $k_{\text {ref }}$ is the reaction rate at the reference temperature, $E_{\mathrm{a}}$, the activation energy (previously determined under isothermal conditions), $R$, the universal gas constant, $T$, the absolute temperature, and $T_{\text {ref, }}$, the reference temperature $(258.15 \mathrm{~K})$.

In the isothermal study, a first-order reaction (Eq. (6)) fitted well the ascorbic acid experimental data. While in the colour evaluation, the parameters were estimated from a zero-order reaction (Eq. (7)) (Gonçalves et al., 2009).

$\frac{C_{(\mathrm{t})}}{C_{0}}=\exp \left(-k_{T} t\right)$

$C_{(\mathrm{t})}=C_{0}-k_{T} t$

Under non-isothermal conditions, since $T=f(t)$, the ascorbic acid and hue angle values can be predicted, for a given time, by Eqs. (8) and (9), respectively.

$C_{(t)}=C_{0} \exp \left\{-k_{\text {ref }} \int_{0}^{t} \exp \left[-\frac{E_{a}}{R}\left(\frac{1}{T_{(t)}}-\frac{1}{T_{\text {ref }}}\right)\right] d t\right\}$

$C_{(t)}=C_{0}-k_{\text {ref }} \int_{0}^{t} \exp \left[-\frac{E_{a}}{R}\left(\frac{1}{T_{(t)}}-\frac{1}{T_{\text {ref }}}\right)\right] d t$

\section{Statistical analysis}

Calculations were performed using the statistical software SPSS 17.0. One-way analysis of variance (ANOVA) was carried out to determine if there were significant differences between each step of the plan of temperature abuses. The Least Significant Difference

\begin{tabular}{|c|c|c|c|}
\hline & Fresh & Blanched & Frozen \\
\hline$L$ & $35.36 \pm 0.37$ & $31.02 \pm 0.91$ & $29.05 \pm 2.53$ \\
\hline$a$ & $-10.35 \pm 0.03$ & $-10.47 \pm 0.17$ & $-4.58 \pm 0.74$ \\
\hline$b$ & $12.30 \pm 0.16$ & $9.05 \pm 0.21$ & $3.97 \pm 1.31$ \\
\hline Chroma & $16.08 \pm 0.14$ & $13.84 \pm 0.25$ & $6.08 \pm 1.39$ \\
\hline Hue angle $\left({ }^{\circ}\right)$ & $130.07 \pm 0.29$ & $139.16 \pm 0.43$ & $139.94 \pm 5.89$ \\
\hline $\mathrm{AA}\left(\mathrm{mg} 100 \mathrm{~g} \mathrm{fw}^{-1}\right)$ & $35.66 \pm 1.42$ & $4.51 \pm 0.48$ & $4.63 \pm 0.77$ \\
\hline DHAA (mg $\left.100 \mathrm{~g} \mathrm{fw}^{-1}\right)$ & $29.17 \pm 8.31$ & $6.32 \pm 1.06$ & $8.61 \pm 5.17$ \\
\hline Total vitamin $C\left(\mathrm{mg} 100 \mathrm{~g} \mathrm{fw}^{-1}\right)$ & $64.83 \pm 7.85$ & $10.83 \pm 0.58$ & $13.25 \pm 4.43$ \\
\hline
\end{tabular}
(LSD) test was run to determine the significant differences between

Table 1

Watercress colour and vitamin C content before the plan of temperature abuses. 
Table 2

Published watercress AA and hue value kinetic parameters under isothermal conditions (Gonçalves et al., 2009).

\begin{tabular}{lll}
\hline Kinetic parameters & AA & Hue angle $\left(^{\circ}\right)$ \\
\hline$E_{\mathrm{a}}\left(\mathrm{kJ} \mathrm{mol}{ }^{-1}\right)$ & 24.73 & 174.71 \\
$k_{\text {ref }}-15^{\circ} \mathrm{C}\left(\mathrm{d}^{-1}\right)$ & 0.00432 & 0.00287 \\
$C_{0}$ & $32.62 \mathrm{mg} 100 \mathrm{~g}^{-1}$ & 132.35 \\
Kinetic model & First-order & Zero-order \\
\hline
\end{tabular}

the control (without abuses) and each treatment. Evaluations were based on a significance level of $5 \%$.

\section{Results and discussion}

\section{Quality parameters}

The experimental values for watercress colour and vitamin $C$ content before the plan of temperature abuses are shown in Table 1 . The applied blanching process, aiming $90 \%$ reduction of the enzyme peroxidase, caused some colour changes and degradation on the vitamin C content. From Fig. 2, it can be observed that, after blanching, the $L$ and $b$ parameters decreased about $12 \%$ and $26 \%$, respectively, showing that the samples became darker and less yellow. On the other hand, the $a$ parameter did not change after the blanching treatment. Colour changes after blanching could be related with the replacement of the gases inside the intercellular spaces by the blanching medium, altering light refraction from the cell surface (Bowers, 1992).

In terms of microstructure quality, the fresh sample (Fig. 3a and a') showed the parenchyma cells and vascular tissue turgid and well defined. The blanched watercress microstructure (Fig. 3b and b') presented the parenchyma cells filled with spherical structures (probably chloroplasts released from inside the cells). The blanched samples also showed a more damaged microstructure, being the tissue firmness and cell wall strength rapidly lost due to the heat extent.

Under thermal blanching, the cell wall membrane may be damaged and allow water to enter the cell. Internal organelles may be distorted and begin to leak their contents. A reduction of cell turgidity is caused by the loss of cell membrane function. Moreover,

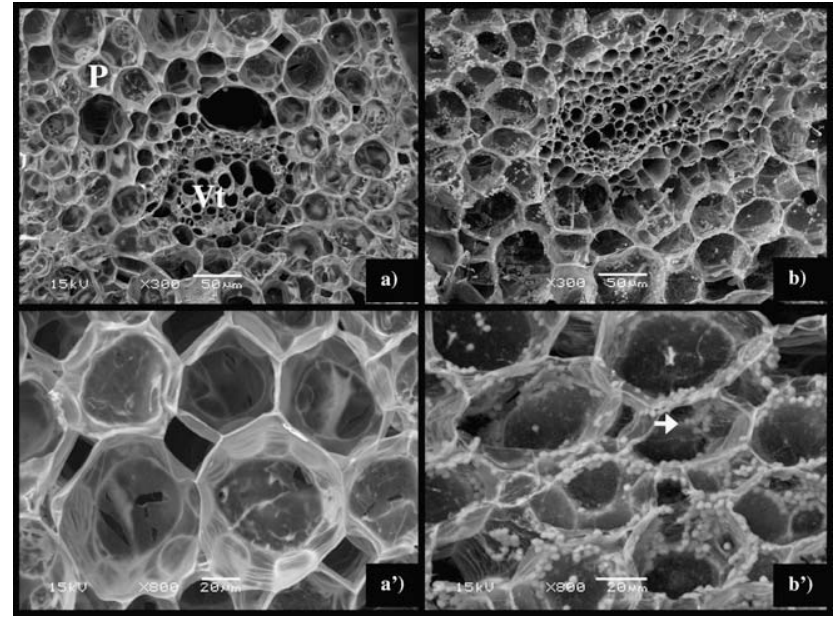

Fig. 3. SEM micrographs of watercress cross section tissue at different magnification levels $(300 \times$ and $800 \times)$ : (a and a') Fresh watercress; (b and b') Blanched watercress. $\mathrm{P}=$ parenchyma cells, $\mathrm{Vt}=$ vascular tissue, white arrow indicate the chloroplasts.

pectic substances are released from the cell wall. This causes less cohesion between adjacent cells and thus a breakdown of the structure (Kerr, 2004).

Throughout the plan of temperature abuses the results showed some variations $(P<0.05)$ in the $L$ parameter between the samples with, and samples without, temperature abuses (Fig. 2). The samples with six, seven, twelve and thirteen weeks of storage, showed the highest differences comparing with the non abused samples. The lightness variations were probably due to the ice crystals formation or water loss along the temperature abuses.

The $b$ parameter showed no significant differences $(P>0.05)$ between the control and all the steps until the end of the plan, meaning that the yellowness was not affected by the temperature fluctuations (Fig. 2).

Although in the $a$ parameter, significant differences $(P<0.05)$ were detected between the control and the $S 2$ step $\left(1 \mathrm{~h}\right.$ at $\left.25^{\circ} \mathrm{C}\right)$, the observed experimental data during the plan of temperature abuses did not reveal any trend, stabilising during the consumer product storage.

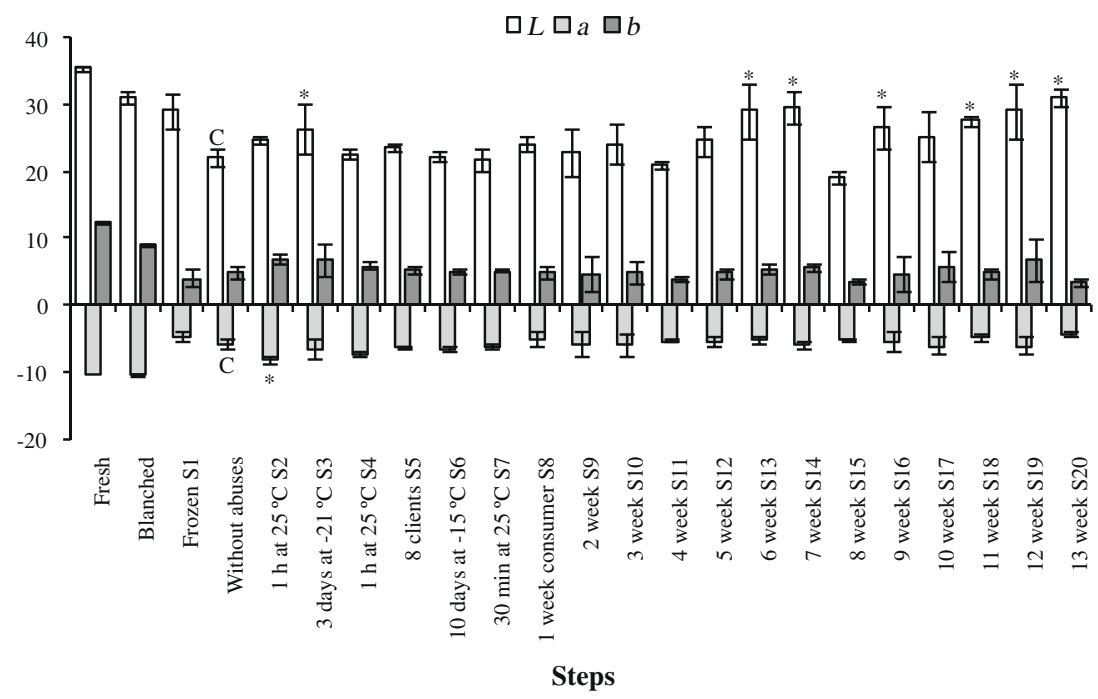

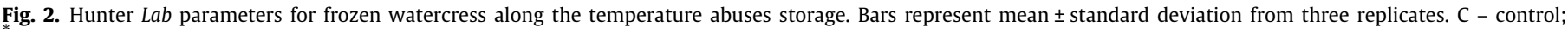
significant differences with control $(\alpha=0.05)$. 
The TCD values showed some fluctuations along the plan with an average value of 4 (Fig. 4). These results are in agreement with those reported by Gormley et al. (2002) in which frozen strawberries submitted to temperature fluctuations showed values of TCD in the same range.

The chroma decreased after freezing about 50\% (less saturated) and showed no significant differences $(P>0.05)$ between all the steps throughout the temperature plan (Fig. 4).

The hue angle (Fig. 5) increased from fresh to blanched watercress suggesting that the samples became greener after processing, corroborating the observed $a$ parameter values. Along the temperature abuses, the samples showed values between $135-145^{\circ}$ and significant differences $(P<0.05)$, only between the control and the $S 13$ step (sixth week at the consumer).

Fig. 6 presents the ascorbic and dehydroascorbic acids and total vitamin $C$ contents throughout the storage plan. The results showed some fluctuations $(P<0.05)$ in both active forms. In terms of dehydroascorbic acid, the product purchase step showed the lowest value observed $(P<0.05)$. This result was probably due to the temperature increase and the consequently conversion of the dehydroascorbic acid to 2,3-diketogulonic acid.

The watercress total vitamin $C$ also showed some fluctuation. The variation throughout the temperature abuses plan is mainly due to the temperature fluctuations. However, that variation can also be associated to the watercress vitamin $C$ initial variability. Nevertheless, the vitamin $C$ value from the beginning until the end of the plan was practically maintained.

In a work reported by Rácz and Szabolcs (1978), with spinach purée under the conditions of the distribution chain, the vitamin C content decreased with storage time and temperature. However, the watercress results in this work are in agreement with those reported by Gormley et al. (2002), in which the vitamin C of frozen strawberries, submitted to temperature fluctuations, was practically maintained when compared to the control.

Sousa et al. (2005) verified in a study with frozen raspberry that temperature is a much more important factor than storage time in

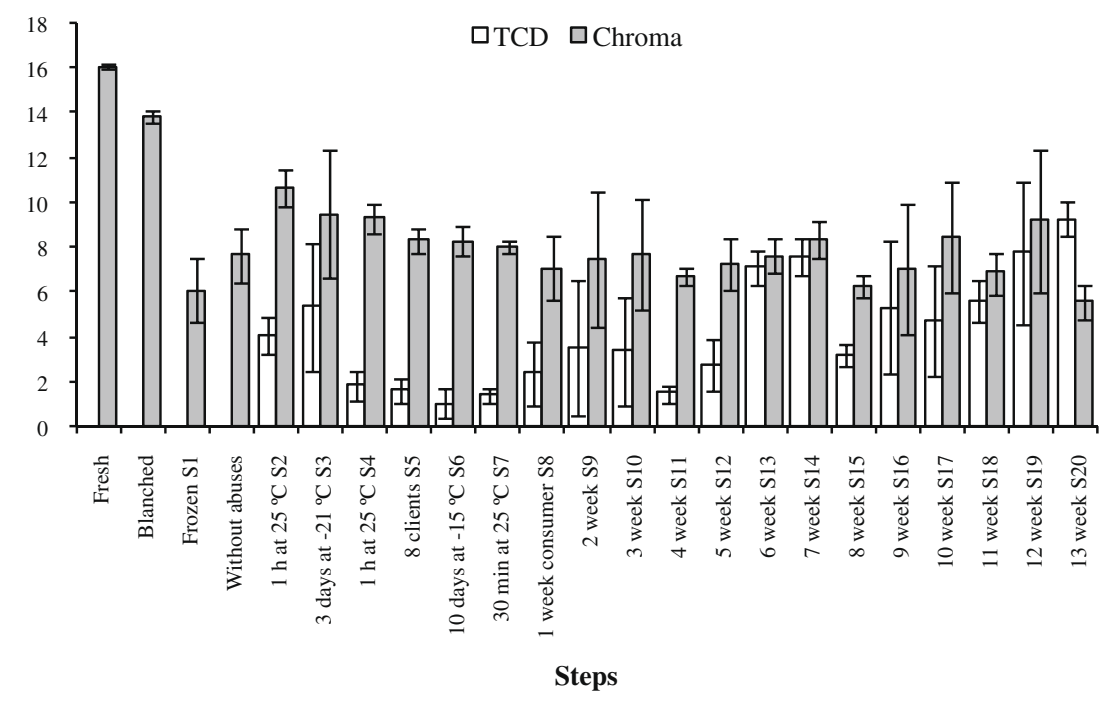

Fig. 4. TCD and chroma parameters for frozen watercress along storage with temperature abuses. Bars represent mean \pm standard deviation from three replicates.

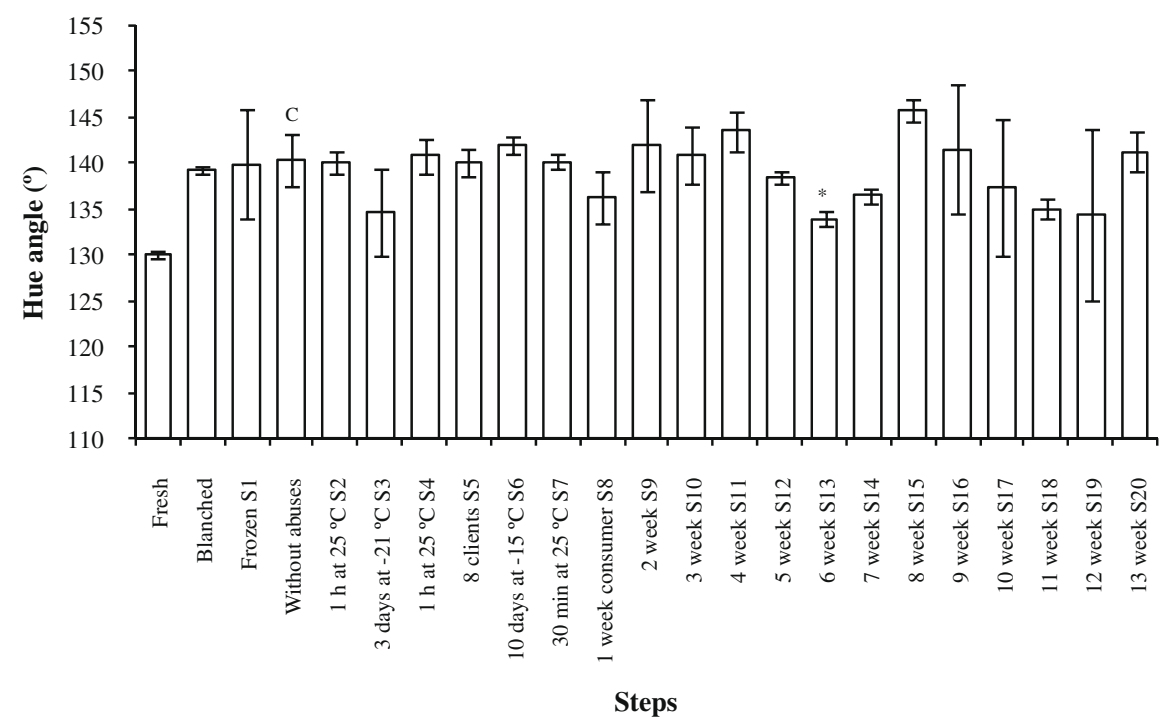

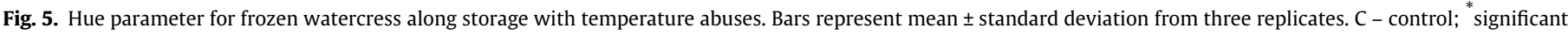
differences with control $(\alpha=0.05)$. 
determining quality loss. Short term frozen storage with fluctuations caused a decrease in the ascorbic acid content of the raspberry fruits.

In a study with frozen spinach at constant temperature, samples stored at $-29^{\circ} \mathrm{C}$ during one year showed ascorbic acid losses of $10 \%$, while at $-12{ }^{\circ} \mathrm{C}$ the initial content decreased $50-75 \%$ (Watt, 1977).
The retention of ascorbic acid in frozen products is thus strongly dependent on their temperature history. The level of vitamin C, besides being an indicator of nutrient value, can be used, in the case of frozen vegetables, as a reliable and representative index for estimating the quality deterioration at any point of the marketing route of a product to its final destination, the consumer (Giannakourou and Taoukis, 2003; Fennema, 1977).

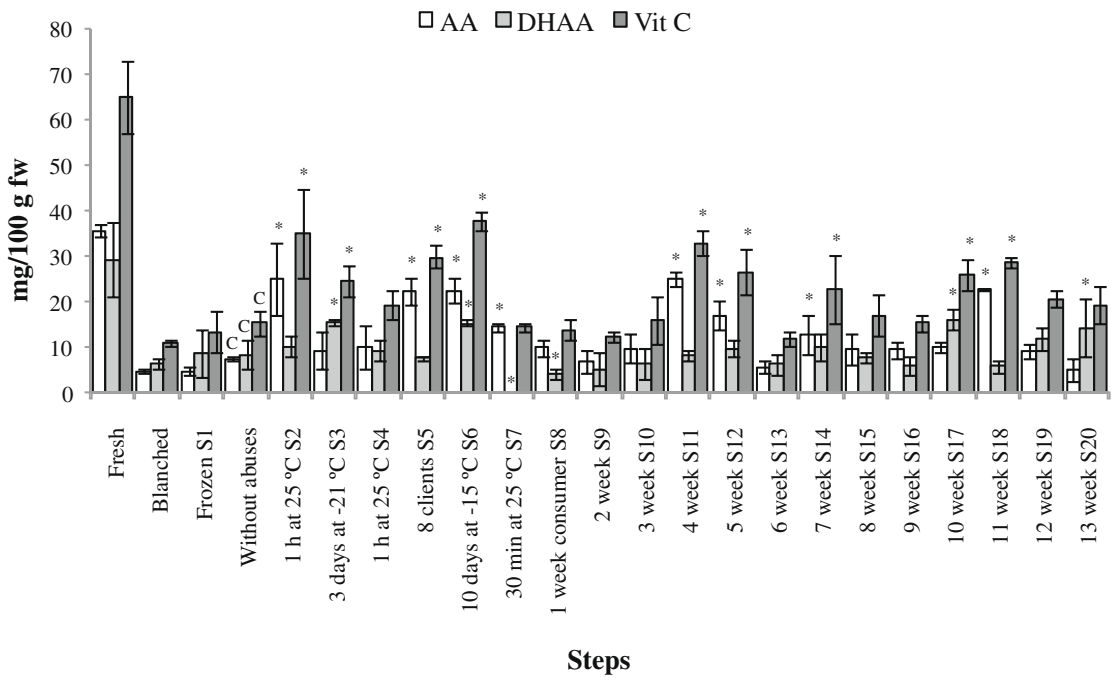

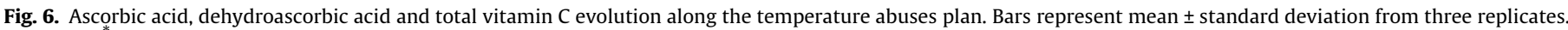
C-control; significant differences with control $(\alpha=0.05)$.

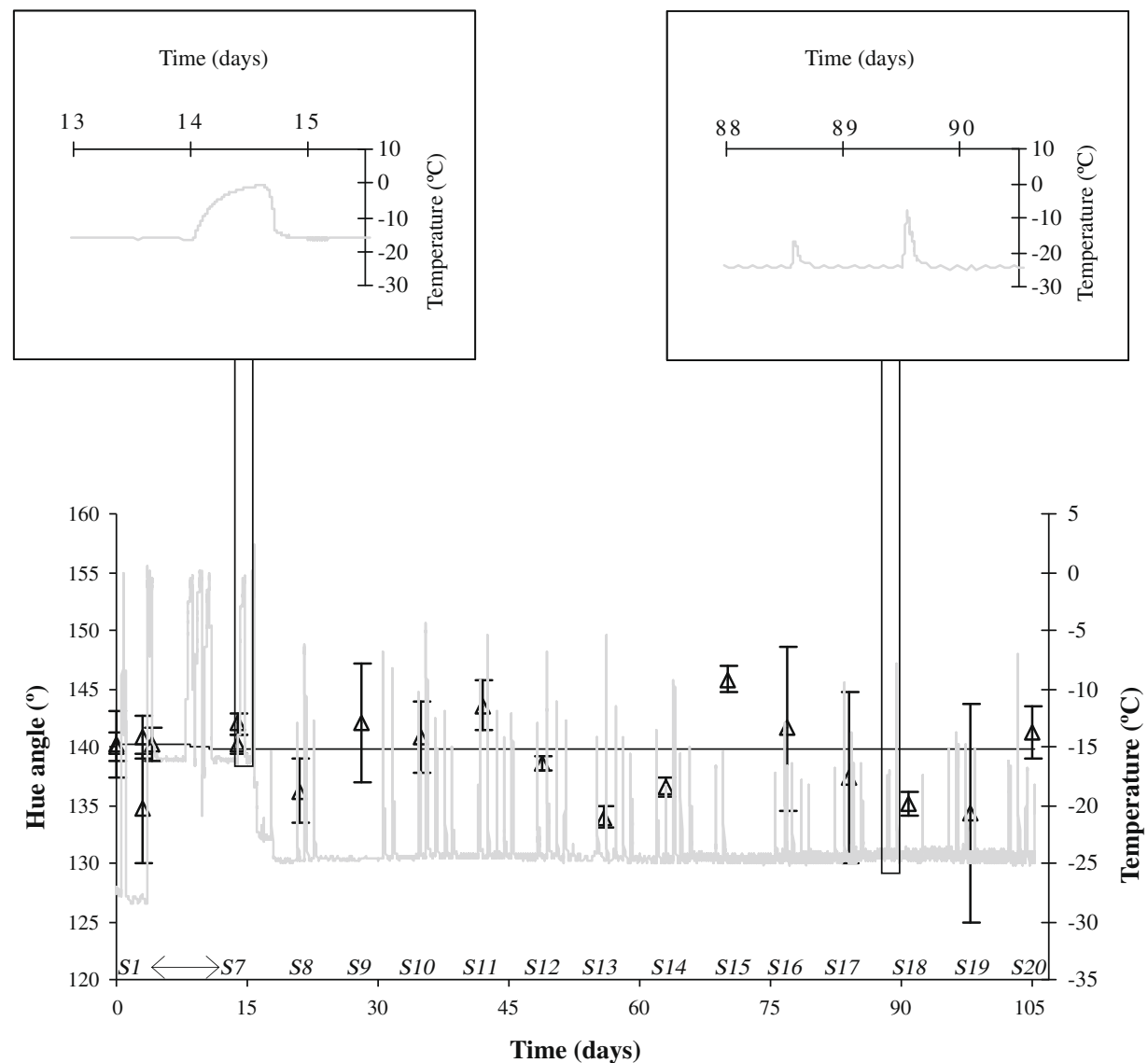

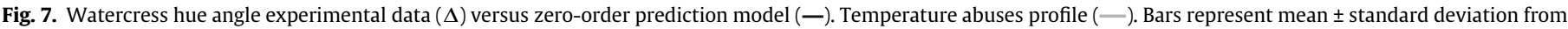
three replicates. Small charts represent two specific temperature abuses profiles. 


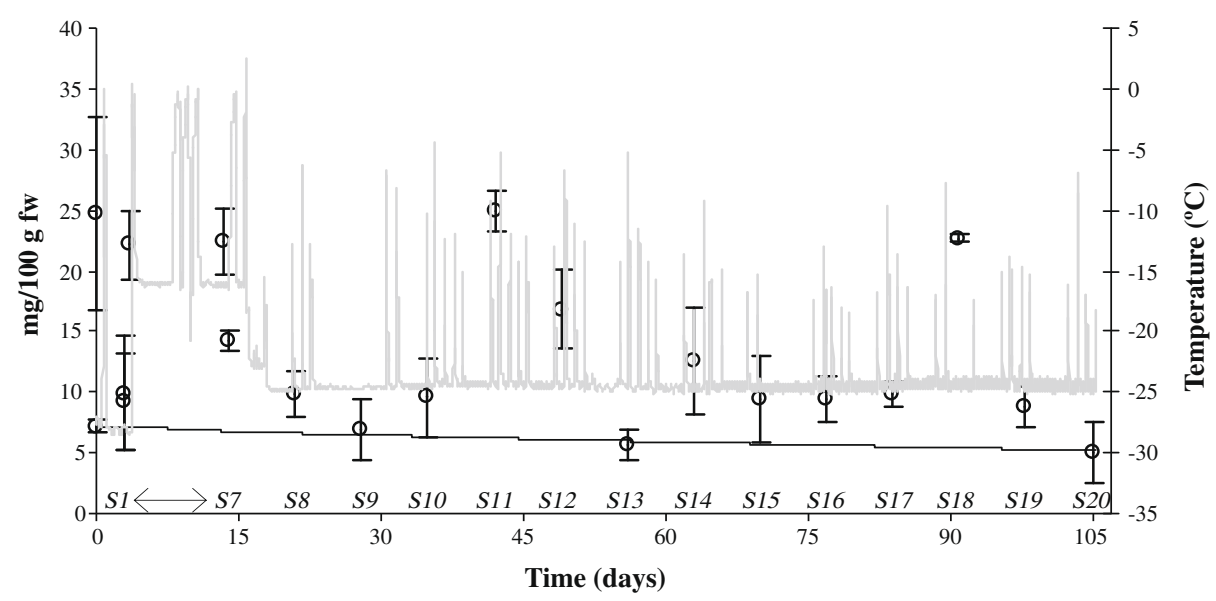

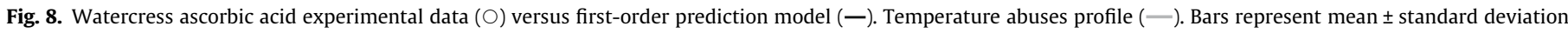
from three replicates.

Interlaboratory temperature abuse studies on frozen foods, conducted as part of the EU Concerted Action project 'The Preservation of Frozen Food Quality and Safety throughout the Distribution Chain', were reported by Bøgh-Sørensen (1999). The simulations were run in the outermost corner of a pallet of frozen food placed at room temperature, in a display cabinet and during transport of frozen food products to the home. The results indicated small effects on product quality.

The quality of the frozen product, submitted to temperature abuses, is probably dependent, besides other factors previously re-

Table 3

Published AA kinetic parameters for other vegetables under frozen storage (Giannakourou and Taoukis, 2003).

\begin{tabular}{lllll}
\hline Kinetic parameters & Green peas & Spinach & Green beans & Okra \\
\hline$E_{\mathrm{a}}\left(\mathrm{kJ} \mathrm{mol}^{-1}\right)$ & 97.9 & 112 & 101.5 & 105.9 \\
$\left.k_{\mathrm{ref}}-20{ }^{\circ} \mathrm{C}^{-1}\right)$ & 0.00213 & 0.00454 & 0.00223 & 0.00105 \\
$C_{0}\left(\mathrm{mg}^{-1} 00 \mathrm{~g}^{-1}\right)$ & 28.5 & 31.1 & 25.3 & 28 \\
$R^{2}$ & 0.958 & 0.992 & 0.967 & 0.868 \\
Kinetic model & First-order & First-order & First-order & First-order \\
\hline
\end{tabular}

Spinach

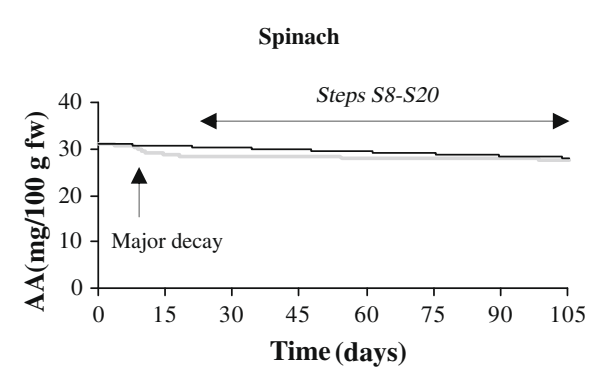

Green beans

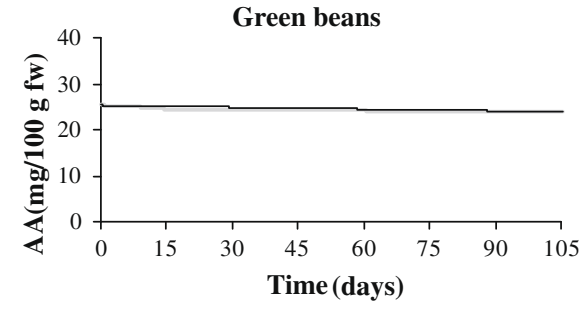

ferred, on the temperature simulation plan and on the raw material used in the study.

In general, sensory (colour) and nutritional (vitamin C) quality of the frozen watercress was not impaired by the imposed temperature abuses. The reason of this behaviour might have been due to the blanching process applied, which contributed to the stabilisation of the frozen watercress during storage.

\subsection{Time temperature profile and quality parameters prediction}

In order to compare the experimental effect of temperature abuses on watercress ascorbic acid and hue angle with the prediction models (Eqs. (8) and (9), respectively), the experimental data were plotted against the prediction models values using kinetic parameters determined under isothermal conditions (Table 2).

The hue angle results showed that the prediction model obtained with the isothermal kinetic parameters fitted well the experimental data with the temperature abuses (Fig. 7). In what concerns ascorbic acid, the fluctuation of the experimental content showed higher values than the prediction (Fig. 8). Nevertheless,
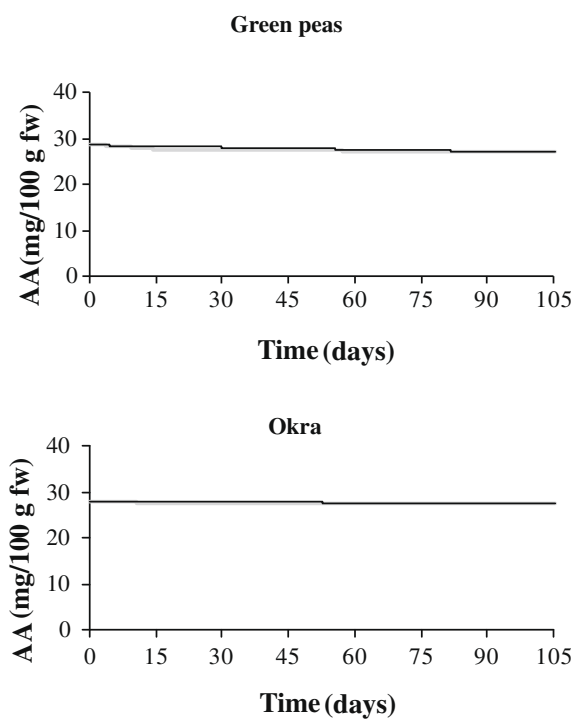

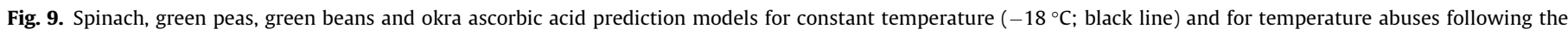
storage plan (grey line). 
some experimental points and the final value were in the same range of the predicted ascorbic acid values (about $7 \mathrm{mg} 100 \mathrm{~g} \mathrm{fw}^{-1}$ ).

Ascorbic acid profiles for other green vegetables were also simulated using kinetic data from Giannakourou and Taoukis (2003) (Table 3). It was possible to conclude that spinach was predicted more sensitive to the imposed temperature abuses rather than green beans, green peas, okra (Fig. 9) and watercress (Fig. 8). It was also concluded that the first fifteen days of simulation (transportation from factory to store; S1-S6) were crucial for the decay of AA content, since from that point until the end of the plan (customer storage) the AA was decreasing at a lower rate.

These behaviours are related to the properties of each vegetable. The watercress samples are slabs and the heat transfer is completely different from leaves like in the Giannakourou and Taoukis (2003) spinach study, were its surface area is higher and it is not well protected like the watercress slabs. Nevertheless, a good prediction is always dependent on the estimated kinetic parameters under the isothermal studies and its application under different dynamic temperature conditions.

\section{Conclusion}

The applied blanching process, although it caused degradation on the vitamin $\mathrm{C}$ content and some colour and microstructure changes, might have contributed to the stability of the frozen product during storage. In general, the physical and nutritional studied parameters of the frozen watercress were not impaired by the imposed temperature abuses.

Freezing offers today a large number of advantages demanded by the consumer, e.g. preserving surplus raw material and bridging seasonal gaps in the food supply, as well as convenience, availability, consistent quality and safety.

The main problems affecting the frozen food industry for many years have been related to the storage time and product temperatures, not so much on the basic knowledge of maintaining shelf life, but on handling storage and transport time and temperatures. The quality and acceptance of frozen foods can be further improved if a greater emphasis is laid on avoiding temperature abuses. The need for lower and steady temperatures is fully accepted by everyone involved in the food chain (Eek, 2001).

From an industrial and commercial point of view, the storage stability (with the studied temperature abuses) of frozen watercress slabs represents a valuable advantage for distributors and retailers, and is also a convenient and healthy option to the final consumer.

This kind of study is an important tool, allowing the prediction of the outcome of different storage and distribution conditions, aiming to improve the products quality and cold chain settings.

\section{Acknowledgments}

The author Rui M.S. Cruz gratefully acknowledges his PhD Grant SFRH/BD/9172/2002 to Fundação para a Ciência e a Tecnologia (FCT) from Ministério da Ciência e do Ensino Superior. The authors thank the Vitacress Company for supplying the raw watercress.

\section{References}

Alvarez, M.D., Canet, W., 1998. Effect of temperature fluctuations during frozen storage on the quality of potato tissue (cv. Monalisa). Zeitschrift Fur Lebensmittel-Untersuchung Und-Forschung A-Food Research And Technology 206, 52-57.

Blond, G., Le Meste, M., 2004. Principles of frozen storage. In: Hui, Y.E., Cornillon, P., Legaretta, I.G., Lim, M.H., Murrell, K.D., Nip, W. (Eds.), Handbook of Frozen Foods. Marcel Dekker, New York (pp. 25-53).

Bøgh-Sørensen, L. (1999). Collaborative study on the temperature abuse of frozen foods. In: Proceedings of the Sixth Plenary Meeting of the EU Concerted Action Project. The Preservation of Frozen Food Quality and Safety throughout the Distribution Chain (CT96-1180). Instituto Sperimentale per la Valorizzazione Technologica dei Prodotti Agricoli, Milan, pp. 9-10.

Bowers, J., 1992. Food Theory and Applications. In: Bowers, J. (Ed.). Macmillan Publisher, New York, pp. 738-739.

Canet, W., 1989. Quality and stability of frozen vegetables. In: Thorne, S. (Ed.), Developments in Food Preservation. Elsevier, London, pp. 1-50.

Cruz, R.M.S., Vieira, M.C., Silva, C.L.M., 2006. Effect of heat and thermosonication treatments on peroxidase inactivation kinetics in watercress (Nasturtium officinale). Journal of Food Engineering 72 (1), 8-15.

Eek, L., 2001. Unlocking the secrets of the freezer. Preservation, 50-52.

Estrada-Flores, S., 2002. Novel cryogenic technologies for the freezing of food products. The Official Journal of Airah, 16-21.

Fennema, O., 1977. Loss of vitamins in fresh and frozen foods. Food Technology 31 (12), 32-38.

Flair flow Europe, 2000. Managing the cold chain for quality and safety. Technical Manual F-FE 378A/00.

Fonseca, S.C., Silva, C.L., Malcata, F.X., 2005. Microstructural analysis of fresh-cut red bell pepper (Capsicum annuum L.) for postharvest quality optimization. Electronic Journal of Environmental, Agricultural and Food Chemistry 4 (5), 1081-1085.

Giannakourou, M.C., Taoukis, P.S., 2003. Kinetic modelling of vitamin C loss in frozen green vegetables under variable storage conditions. Food Chemistry 83 , 33-41.

Gonçalves, E.M., Cruz, R.M.S., Abreu, M., Brandão, T.R.S., Silva, C.L.M., 2009. Biochemical and colour changes of watercress (Nasturtium officinale R. Br.) during freezing and frozen storage. Journal of Food Engineering 93, 32-39.

Gormley, R., Walshe, T., Hussey, K., Butler, F., 2002. The effect of fluctuating vs constant frozen storage temperature regimes on some quality parameters of selected food products. Lebensmittel-Wissenschaft und Technologie 35, 190-200.

HunterLab, 2000. Applications notes 12 (5), 1-8.

Kerr, W.L., 2004. Texture in frozen foods. In: Hui, Y.E., Cornillon, P., Legaretta, I.G., Lim, M.H., Murrell, K.D., Nip, W. (Eds.), Handbook of Frozen Foods. Marcel Dekker, New York, pp. 149-150.

Mountney, G.J., Gould, W.A., 1988. Low-temperature food preservation. In: Practical Food Microbiology and Technology, third ed. Van Nostrand Reinhold Company, New York, pp. 112-115 (Chapter 7).

Oliveira, S.R., Cruz, R.M.S., Vieira, M.C., Silva, C.L.M., Gaspar, M.N., 2009. Enterococcus faecalis and Pseudomonas aeruginosa behaviour in frozen watercress (Nasturtium officinale) submitted to temperature abuses. International Journal of Refrigeration 32, 472-477.

Pala, M., 1983. Effect of different pretreatments on the quality of deep frozen green beans and carrots. International Journal of Refrigeration 6, 237-246.

Pizzocaro, F., Senesi, E., Querro, O., Gasparoli, A., 1995. Blanching effect on carrots. Study of the lipids stability during the frozen conservation. Industrie Alimentari 34, 1265-1272.

Rácz, E., Szabolcs, L., 1978. Changes in the quality of quick-frozen spinach crème under the conditions of the distribution chain, in cooling, freezing, storage and transport: biological and technical aspects. In: Refrigeration Science and Technology. International Institute of Refrigeration, Hungary, pp. 73-84.

Sousa, M.B., Canet, W., Alvarez, M.D., Tortosa, M.E., 2005. The effect of the pretreatments and the long and short-term frozen storage on the quality of raspberry (cv. Heritage). European Food Research and Technology 221, 132-144.

US Department of Agriculture, Agricultural Research Service, 2003. USDA National Nutrient Database for Standard Reference, Release 16.

Watt, B.K., 1977. Nutritive value of frozen foods. In: Desroier, N.W., Tressler, D.K. (Eds.), Fundamentals of food freezing. Avi Publishing, Westport (p. 528).

Zapata, S., Dufour, J., 1992. Ascorbic, dehydroascorbic and isoascorbic acid simultaneous determinations by reverse phase ion interaction HPLC. Journal of Food Science 57, 506-511. 